
Jurnal Pangan dan Agroindustri Vol. 9 No.3: 165-172, Juli 2021

Accepted: 14/12/2020, Reviewed: 06/05/2021, Published: 30/07/2021

\title{
SYNTHESIS OF FOOD GRADE SALT FROM BRINE WATER OF TIRTA SANITA BOGOR
}

\author{
Ermiziar Tarmizi, Kudrat Sunandar*, Agam Duma Kalista Wibowo \\ Department of Chemical Engineering, Institut Teknologi Indonesia \\ JI. Raya Puspitek - Serpong \\ *Correspondence Author, email: k_sunandar@iti.ac.id
}

\begin{abstract}
Tirta Sanita Bogor brine water contains high concentrations of sodium ( $\mathrm{Na}$ ). It also contains calcium (Ca) and magnesium (Mg). The purpose of this research is to make the food grade salt with relatively low Ca and Mg content. The process was carried out in two methods, the first method was chemical precipitation which was divided into two stages, the removal of the $\mathrm{Mg}$ element using a limestone compound $\left(\mathrm{CaCO}_{3}\right)$ which has been calcined at $900^{\circ} \mathrm{C}$ for 6 hours, and the removal of $\mathrm{Ca}$ element using $\mathrm{Li}_{2} \mathrm{CO}_{3}$ compound. The second method was traditional evaporation which was conducted using prism greenhouse technology. The brine filtrate was reacted with $\mathrm{Na}_{2} \mathrm{CO}_{3}$ and the results were analyzed using the ICP-OES. The results showed that the $\mathrm{NaCl}$ content was $80 \%$ by the chemical precipitation and traditional evaporation methods.
\end{abstract}

Keywords: Brine water, Precipitation, Evaporation, Food grade salt

\section{INTRODUCTION}

Indonesia has a number of beaches with the overall area of about $54,716 \mathrm{~km}^{2}$. These beaches stretch across the archipelago from Sabang to Papua. However, the long coast does not guarantee that it is able to meet the needs of domestic salt production. This is due to a short dry season (4 to 5 months), high humidity (60-70\%), traditional salt production equipment and methods. As a result, the salt quality is relatively low (88-92.5\%).

Salt is a chemical compound called sodium chloride $(\mathrm{NaCl})$. This compound is hygroscopic, so that it can not be obtained in completely pure form. According to the Ministry of Trade, salt is a compound which main component consists of sodium chloride $(\mathrm{NaCl})$ and contains other compounds such as water, magnesium, calcium, and sulfate ions. Based on its utilization, salt is classified into two groups, namely table salt and industrial salt. According to $\mathrm{SNI}$, table salt has a minimum $\mathrm{NaCl}$ content of $95 \%$ (Tansil et al., 2016). For industrial salt, better quality is highly needed, for example, in the petroleum industry, the $\mathrm{NaCl}$ content is $97 \%$ (Rismana, 2014) the textile and leather tanning industry requires $\mathrm{NaCl}$ content above $97.5 \%$, the chlorine alkaline industry requires $\mathrm{NaCl}$ above $98.5 \%$ and the pharmaceutical industry requires above $99.5 \%$. The need for salt in the chemical industry sector is increased significantly every year, therefore the purification of local salt should be grown in order to meet market needs. Table 1 shows the parameter of salt quality based on SNI 01-3556-2000 standards (Rusiyanto et al., 2013).

According to (Yansa et al., 2015) the classification of $\mathrm{NaCl}$ salts has several criteria, such as "very good" with more than $95 \%$ of $\mathrm{NaCl}$ content, "good" criteria, with the $\mathrm{NaCl}$ content between 90 and $95 \%$, and "moderate" criteria, with the percentage from 80 to $90 \%$.

Brine water of Tirta Sanita Bogor contained high concentrations of $\mathrm{NaCl}$ nevertheless, still contained $\mathrm{Ca}$ and $\mathrm{Mg}$ of 38.48 and 146.02 ppm respectively (Lalasari et al., 2019). This is the reason why Tirta Sanita Bogor brine water has potency to produce industrial salt with food grade quality. The aim of this research is to study the salt from brine water of Tirta Sanita Bogor from non-food grade to food grade quality salt. The processing was carried out in two 
methods, the first method was used chemical precipitation and the second method was applied the traditional evaporation.

Table 1. The parameter of salt quality

\begin{tabular}{lc}
\hline \multicolumn{1}{c}{ Compound } & Content \\
\hline Sodium Chloride, $\mathrm{NaCl}$ & $\min .94 .7 \%$ \\
Water & $\max .5 \%$ \\
lodine as $\mathrm{KIO}_{3}$ & $30-80 \mathrm{mg} / \mathrm{kg}$ \\
Calcium and Magnesium & $1.00 \%$ \\
Sulfate, $\mathrm{SO}_{4}{ }^{2-}$ & $2.00 \%$ \\
\hline
\end{tabular}

Source: (Rusiyanto et al., 2013)

The first method of chemical precipitation included: the process of removing magnesium $(\mathrm{Mg})$ using $150 \%$ excess limestone $(\mathrm{CaO})$ which has been calcined at $900^{\circ} \mathrm{C}$ for 6 hours (Firdiyono et al., 2020)The Mg removal reaction was conducted by the formation mechanism of $\mathrm{Mg}(\mathrm{OH})_{2}$ precipitates and followed by filtration. The second stage was the removal of the calcium $(\mathrm{Ca})$ using the $\mathrm{Li}_{2} \mathrm{CO}_{3}$ therefore, the $\mathrm{CaCO}_{3}$ precipitates was formed and removed $\mathrm{Mg}$ by the formation of $\mathrm{MgCO}_{3}$ precipitates simultaneously. Brine filtrate which was expected to be nearly free from $\mathrm{Mg}$ and $\mathrm{Ca}$ was reacted with $\mathrm{Na}_{2} \mathrm{CO}_{3}$ (Sumarno, Ratnawati \& Nugroho 2012) to obtain Na salt. The second method of traditional evaporation was executed by using prism greenhouse technology, the salt was washed and separated from impurities and the result was compared with the salt from the literature.

\section{METHODOLOGY}

\section{Materials}

The materials used are shown in Table 2.

Table 2: The list of chemicals

\begin{tabular}{ll}
\hline \multicolumn{1}{c}{ Materials } & \multicolumn{1}{c}{ Specification } \\
\hline Brine Water & Brine water of Tirta Sanita Bogor \\
$\mathrm{CaCO}_{3}$ & Rembang Limestone (Technical) \\
$\mathrm{Li}_{2} \mathrm{CO}_{3}$ & Merck, solid $(99.997 \%)$ \\
$\mathrm{Na}_{2} \mathrm{CO}_{3}$ & Merck, solid $(99.99 \%)$ \\
Distilled water & Clear \\
\hline
\end{tabular}

\section{Equipment:}

The equipment used consist of

a) Reflux equipment includes:

1) Stative rod 2) clamp, 3) Condenser, 4) Thermometer, 5) Three neck flask, 6) Cool water bath 7) Magnetic stirrer, 8) Hotplate and Magnetic Stirrer.

b) Filtration equipment (filtering) consist of:

1) Stative rod 2) clamp 9) Whatman filter paper No. 41, 10) Separating Funnel, and 11) Beaker Glass. 


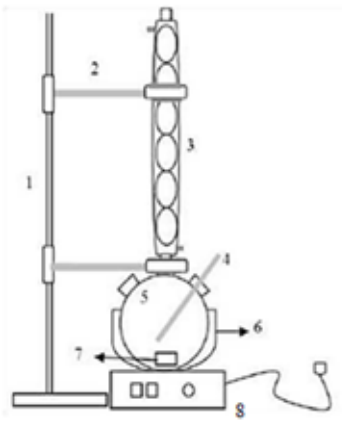

(a)

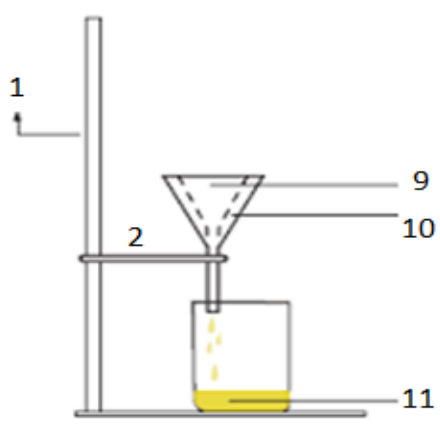

(b)

Figure 1.(a) Reflux equipment set and (b) Filtrating equipment set (Lalasari dkk, 2019)

\section{Research design:}

Method 1 - Preparation of $\mathrm{Na}$ salts by chemical precipitation

- Raw materials preparation, including the filtering of brine water from the prism greenhouse.

- Chemical Precipitation 1 (removal process of Mg)

- Amount of 482.44 grams of $\mathrm{CaO}$ was added to $4 \mathrm{~L}$ of brine water and then continued by filtration

- Next, stirring was performed for 3 hours by magnetic stirrer

- After that, the filtration was conducted. The results was called filtrate A.

- Chemical Precipitation 2 (removal process of $\mathrm{Ca}$ )

- Amount of $10 \mathrm{~mL}$ of filtrate was taken from filtrate $\mathrm{A}$ and then it was added $\mathrm{Li}_{2} \mathrm{CO}_{3}$ with variation of $0,50,100$ and $150 \%$.

- After that, It was refluxed at $30^{\circ} \mathrm{C}$. for 4 hours.

- Furthermore, the filtration was conducted (Figure $1 \mathrm{~b}$ ). The result was called filtrate $B$ which was tested by ICP-OES.

- Finally, amount of $50 \mathrm{~mL} \mathrm{Na} \mathrm{CO}_{3} 12 \mathrm{~N}$ was added into 1 Liter of filtrate $\mathrm{B}$ to form $\mathrm{Na}$ salt.

Method 2 - Production of Na salt by Traditional Evaporation

- Salt was collected from prism greenhouses

- After that, It was filtered to clean from impurities. Furthermore, the separation was carried out based on the hexagonal salt form.

- Eventually, the salt resulted was compared with its structure in the literature. 
The research diagram is illustrated in Figure 2.

Method 1

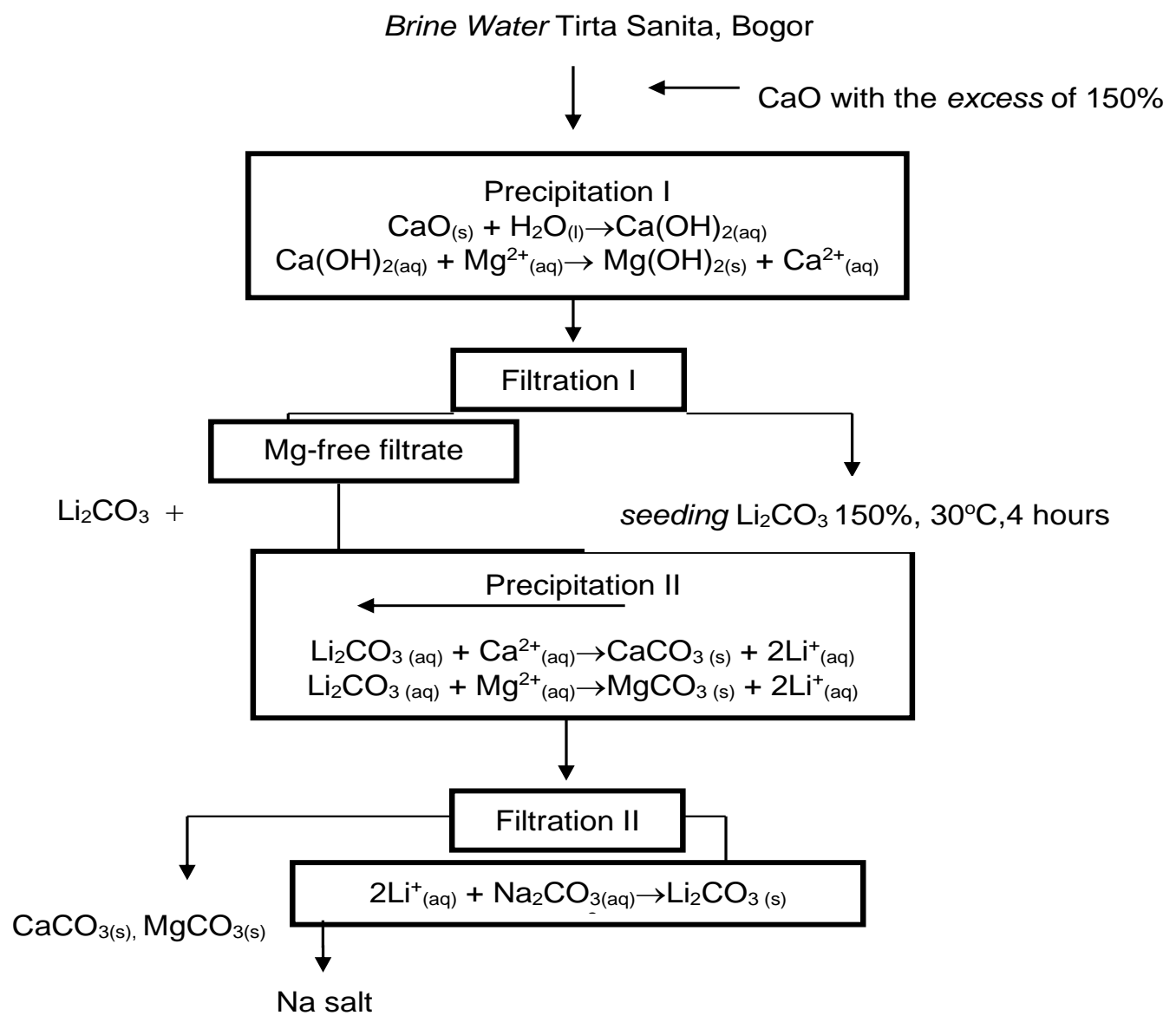

Method 2

Process of Making Na salt

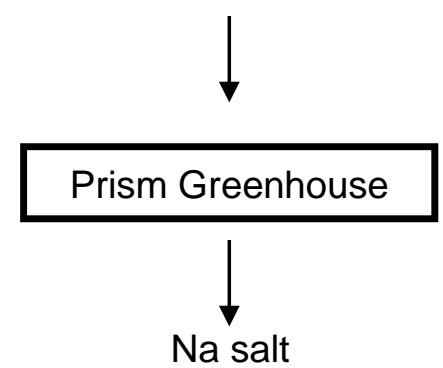

Figure 2. The flowchart of Food Grade Salt production

\section{Research Stages}

The research stage was carried out by two methods:

Method I

Chemical precipitation was performed by removing the magnesium $(\mathrm{Mg})$ using excess of $150 \%$ limestone $(\mathrm{CaO})$ which has been calcined at $900^{\circ} \mathrm{C}$ for 6 hours. (Firdiyono dkk, 2020). The Mg removal reaction was done by the precipitation of $\mathrm{Mg}(\mathrm{OH})_{2}$ and followed by filtration. The second stage was the removal of calcium (Ca) using the $\mathrm{Li}_{2} \mathrm{CO}_{3}$. The $\mathrm{CaCO}_{3}$ precipitate 
was formed and simultaneously removed the remaining $\mathrm{Mg}$ with the formation of $\mathrm{MgCO}_{3}$ precipitate. The Brine filtrate was expected to be free from $\mathrm{Mg}$ and $\mathrm{Ca}$ by $\mathrm{Na}_{2} \mathrm{CO}_{3}$ as reactant to obtain Na salt (Sumarno et al., 2012).

\section{Method II}

The formation of $\mathrm{Na}$ salts with traditional evaporation was conducted by using the prism greenhouse technology (a technology using rectangular building with a geoisolator base and a prism-shaped plastic roof). The salt was obtained from harvesting process. After that, washing process was conducted in order to separate the impurity and followed by crystallization. The salt that has been formed was then compared with salt from the literature.

\section{Analysis Procedurs}

The product analysis in this study was the salt content test using the Inductively Coupled Plasma-Optical Emission Spectrometry (ICP-OES) instrument. The analysis was performed in Metallurgy and Materials Research Center - LIPI, Puspitek, Serpong.

\section{RESULTS AND DISCUSSION}

\section{The formation of Na salts by Using Chemical Precipitation Method}

Based on the research of Lalasari et al., (2019), the content of Brine water of Tirta Sanita Bogor contained $\mathrm{Ca}, \mathrm{Mg}$, $\mathrm{Li}$ and $\mathrm{Na}$ components with concentration of 384.866, 147.227, 746.748 and $877.891 \mathrm{ppm}$ respectively. According to (Aprilianti \& Gustiawati, 2016) study, the content of brine, $\mathrm{Na}$ has had range from 25.000 to $100.000 \mathrm{ppm}, \mathrm{Mg}$ and $\mathrm{Ca}$ was about 57.000 and $75.000 \mathrm{ppm}$ respectively. Based on the first precipitation (Mg removal), filtrate A was based on the following reaction

$$
\begin{aligned}
& \mathrm{CaO}(\mathrm{s})+\mathrm{H}_{2} \mathrm{O}_{(\mathrm{l})} \rightarrow \mathrm{Ca}(\mathrm{OH})_{2(\mathrm{aq})} \\
& \mathrm{Ca}(\mathrm{OH})_{2(\mathrm{aq})}+\mathrm{Mg}^{2+}{ }_{(\mathrm{aq})} \rightarrow \mathrm{Mg}(\mathrm{OH})_{2(\mathrm{~s})}+\mathrm{Ca}^{2+}{ }_{(\mathrm{aq})} \ldots . . . \text { Reaction } 2
\end{aligned}
$$

\begin{tabular}{|c|c|}
\hline Element & Concentration (ppm) \\
\hline $\mathrm{Mg}$ & 18.290 \\
\hline $\mathrm{Ca}$ & 820.136 \\
\hline $\mathrm{Li}$ & 951.973 \\
\hline $\mathrm{Na}$ & 782.965 \\
\hline
\end{tabular}

\section{The test results with the IOP-OES instrument are shown in Table 3.}

The analysis results in table 3 shows that the concentration of $\mathrm{Mg}$ has decreased to $18.290 \mathrm{ppm}$, (reaction 2). Mg content in the previous study was $209.353 \mathrm{ppm}$ since some of the $\mathrm{Mg}$ has formed $\mathrm{Mg}(\mathrm{OH})_{2(\mathrm{~s})}$ precipitate. Thus, this shows that the remaining $\mathrm{Mg}$ content in the brine filtrate is around $8.740 \%$.

The results of filtrate $\mathrm{B}$ in reaction stage II (Ca removal) are based on the following reactions:

$$
\begin{aligned}
& \mathrm{Li}_{2} \mathrm{CO}_{3}(\mathrm{aq})+\mathrm{Ca}^{2+}{ }_{(\mathrm{aq})} \rightarrow \mathrm{CaCO}_{3}{ }_{(\mathrm{s})}+2 \mathrm{Li}^{+}{ }_{(\mathrm{aq})} \ldots \ldots \ldots \ldots \text { Reaction } 3 \\
& \mathrm{Li}_{2} \mathrm{CO}_{3}(\mathrm{aq})+\mathrm{Mg}^{2+}{ }_{(\mathrm{aq})} \rightarrow \mathrm{MgCO}_{3}(\mathrm{~s})+2 \mathrm{Li}^{+}{ }_{(\mathrm{aq})} \ldots \ldots \ldots \ldots \text { Reaction } 4
\end{aligned}
$$

This stage was carried out with a variation of $\mathrm{Li}_{2} \mathrm{CO}_{3}$ (excess seeding) at $0,50,100$ and $150 \%$, which was refluxed at $30^{\circ} \mathrm{C}$ for 4 hours. The test results are shown in Figure 3. 


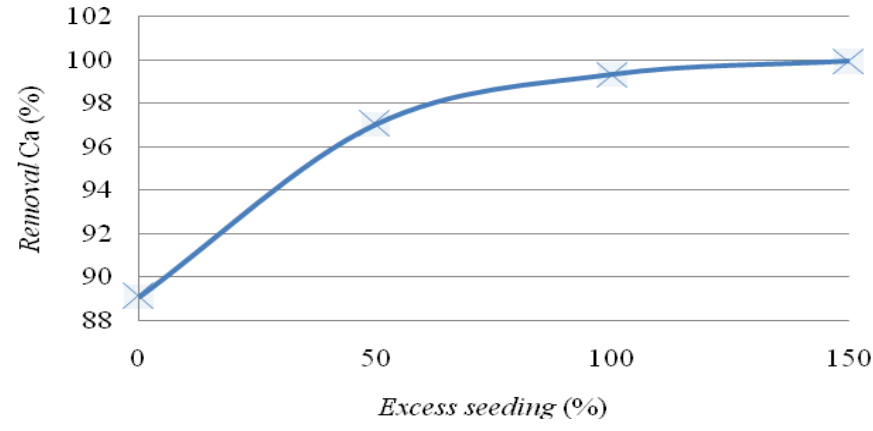

Figure 3. Effect of the Excess on Ca Removal at $30^{\circ} \mathrm{C}$ and 4 Hours

Based on the graph in Figure 3, it can be seen that the removal of $\mathrm{Ca}$ at the temperature of $30^{\circ} \mathrm{C}$ for 4 hours is $99.60 \%$, i.e the remaining $\mathrm{Ca}$ is $0.640 \%$. This is because part of the filtrate has formed $\mathrm{CaCO}_{3(\mathrm{~s})}$. Moreover, some of the remaining $\mathrm{Mg}$ left in the filtrate has also settled into $\mathrm{MgCO}_{3}$ (s). Therefore, there is still $\mathrm{Ca}$ content by $0.640 \%$ in the brine filtrate. After the reduction in the $\mathrm{Ca}$ content at reaction 3 and 4 , there is still Lithium at temperature of $150^{\circ} \mathrm{C}$ with the concentration of $1746 \mathrm{ppm}$. Figure 4 shows the lithium content in the reduction process of $\mathrm{Ca}$ content.

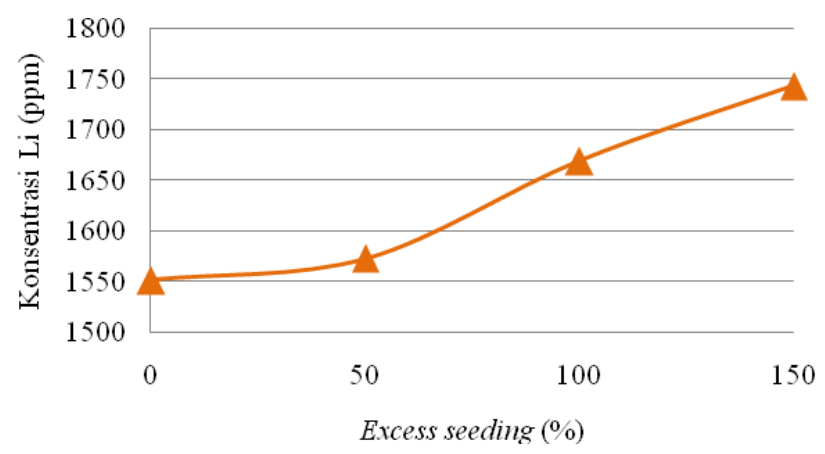

Figure 4. Effect of the Excess on Li Concentration at $30^{\circ} \mathrm{C}$ and for 4 Hours

It can be seen in Figure 4 that the Li concentration in the Brine filtrate is $1746 \mathrm{ppm}$. This indicates that the Lithium content in the 1-liter filtrate is $1746 \mathrm{mg}$. On the other hand, $\mathrm{Na}$ salt can be obtained from the following reaction:

$$
2 \mathrm{Li}^{+}{ }_{(\mathrm{aq})}+\mathrm{Na}_{2} \mathrm{CO}_{3(\mathrm{aq})} \rightarrow \mathrm{Li}_{2} \mathrm{CO}_{3}(\mathrm{~s})+2 \mathrm{Na}^{2+}{ }_{(\mathrm{aq})} \ldots \ldots \ldots \text {. Reaction } 5
$$

According to the reaction 5 above, it means that the $\mathrm{Na}$ salt formed is equivalent to the amount of Lithium salt in amount of 1746 grams. At temperature of $30^{\circ} \mathrm{C}$ for 4 hours, the $\mathrm{Li}$ concentration becomes $1,373.02 \mathrm{mg}$. Thus, the percentage of $\mathrm{Na}$ salt obtained was $78.72 \%$. Furthermore, the portion of $\mathrm{Mg}$ and $\mathrm{Ca}$ was 8.74 and $0.64 \%$ respectively by the chemical precipitation

\section{The Formation of Na salt by Traditional Evaporation Method}

Study to the salt resulted by harvesting which was conducted using a prism greenhouse has already done. The salt was analyzed after the purification from its impurities. There are several forms of $\mathrm{Na}$ salt images, as shown in Figure 5. 


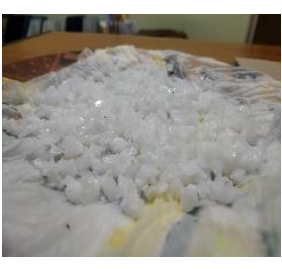

a

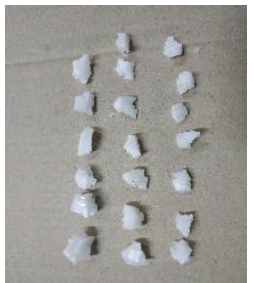

b

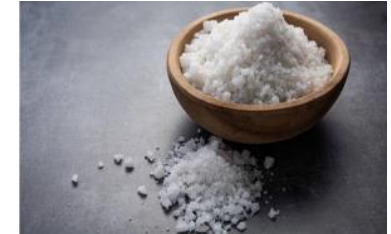

C

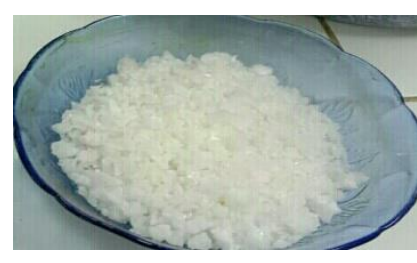

d

Figure 5. Several forms of Salt; a) Salt obtained from prism greenhouse harvest, b) Na salt resulted from separation process of prism greenhouse harvest, c) Na salt from literature, d) $\mathrm{Na}$ salt produced from recrystallization

Based on Figure 5 above, in Figure a) It can be seen different form of salt. This is proved that the salt also contains not only $\mathrm{Na}$ but also $\mathrm{Ca}$ and $\mathrm{Mg}$ as impurities(Arwiyah et al., 2015). Meanwhile, in figure b) shows the Na salt which has been purified from its impurities. It has cube-shaped $\mathrm{Na}$ salt therefore it can be said that this is $\mathrm{Na}$ salt resulted from the harvesting of the prism greenhouse. Furthermore, there is a similarity of shape when compared to the salt in figure $\mathrm{c}$ ) and d), which belongs to the group of medium class of $\mathrm{NaCl}$ salts (Yansa et al., 2015).

By comparing between Na salt from traditional evaporation and in Figure d), it is almost similar. Thus, it can be said that $\mathrm{Na}$ salt obtained by chemical precipitation is almost similar with $\mathrm{Na}$ salt resulted from traditional evaporation. Nevertheless, in terms of health, salt resulted from traditional evaporation is considered more healthier for human since it does not use any chemicals. According to the standard for the quality of salt based on the SNI 01-35562000 (Rusiyanto et al., 2013), the category of food grade salt has $94.7 \%$ of $\mathrm{NaCl}$ content which similar to study by (Yansa et al., 2015) which has $\mathrm{NaCl}$ content from 90 to $95 \%$. On the other hand, the medium class salt has $80 \%$ of $\mathrm{NaCl}$ (Farikh, 2017). Therefore, in this study, the salt resulted by using chemical precipitation and traditional evaporation has food grade salt quality with $80 \%$ of $\mathrm{NaCl}$ and been classified in the medium grade salt.

\section{CONCLUSION}

The results showed that food grade salt from brine water of Tirta Sanita Bogor by chemical precipitation and evaporation is classified in "medium" grade salt with $80 \%$ of $\mathrm{NaCl}$ content.

\section{ACKNOWLEDGMENT}

The authors would like to express their sincere gratitude to the Center for Research and Community Service of the Indonesian Institute of Technology who has funded this research under the contract number 019/KP/PRPM-PP/ITI/VII/2020.

\section{REFERENCES}

Aprilianti, \& Gustiawati. (2016). Peningkatan Kualitas Garam Rakyat dengan Metode Reksristalisasi. ITS. Surabaya.

Arwiyah, A., Zainuri, M., \& Efendy, M. (2015). Studi Kandungan NaCl Di Dalam Air Baku Dan Garam Yang Dihasilkan Serta Produktivitas Lahan Garam Menggunakan Media Meja Garam Yang Berbeda. Jurnal Kelautan, 1(8), 1-9.

Farikh, A. (2017). Kualitas Garam Hasil Produksi Rakyat Dengan Metoda Prisma Rumah Kaca DI Desa Sedayu Lawas Kecamatan Brondong Kabupaten Lamongan, Jawa Timur. Universitas Brawijaya. Malang.

Firdiyono, F., Lalasari, L. H., Tarmizi, E., Sulistiyono, E., Andriyah, L., Arini, T., Natasha, N. C., \& Yunita, E. (2020). The Degree of Lithium (Li) Stability Compared To Calcium (Ca) and Magnesium (Mg) From Low Lithium Grade Brine Water with Addition of Limestone 
and Oxalic Acid. IOP Conf. Ser.: Mater. Sci. Eng., 858(1), 012044.

Lalasari, L. H., Fatahillah, F. R., Rahmat, D., Tarmizi, E. A., Rhamdani, E., Sulistiyono, L., \& Andriyah Firdiyono, F. (2019). Magnesium removal from brine water with low lithium grade using limestone, rembang, indonesia. IOP Conf. Ser.: Mater. Sci. Eng, 578(1), 012067.

Rismana, E. (2014). Kajian Proses Produksi Garam Aneka Pangan Menggunakan Beberapa Sumber Bahan Baku. J Chem. Prog, 7(1), 25-28.

Rusiyanto, Soesilowati, E., \& Jumaeri. (2013). Penguatan Industri Garam Nasional Melalui Perbaikan Teknologi Budi Daya Dan Diversifikasi Produk. Jurnal Sainteknologi, 11(2), 129-142.

Sumarno, Ratnawati, R., \& Nugroho, A. (2012). Recovery Garam Lithium Dari Air Asin (Brine) Dengan Metoda Presipitasi. Jurnal Teknik, 33(2), 66-70.

Tansil, Y., Belina, Y., \& Widjaja, T. (2016). Produksi Garam Farmasi dari Garam Rakyat. Jurnal Teknik ITS, 5(2). https://doi.org/10.12962/j23373539.v5i2.16427

Yansa, H., Sandi, D, H., \& Umra, N, I. (2015). Sea Water Filter With Circle Method Untuk Meningkatkan Produksi Garam Beryodium Menuju Pencapaian Swasembada Garam Nasional Yang Berkelanjutan. Jurnal PENA, 2(1), 1-20. 